Rural geographical research at the University of Aberdeen: working in rural places and with rural communities

Lorna J. Philip ${ }^{\text {a* }}$ and Andrew S. Maclaren ${ }^{a}$

${ }^{a}$ Department of Geography and Environment, School of Geosciences, University of Aberdeen, Aberdeen, Scotland, UK

*1.philip@abdn.ac.uk (corresponding author) 


\title{
Rural geographical research: working in rural places and with rural communities
}

\begin{abstract}
Across a number of disciplines at the University of Aberdeen, there is a long tradition of research focused upon the interrogation of issues associated with rural places and rural communities. Since the mid-1960s, rural geographical research has been a prominent component of the research undertaken by academic staff in Geography. Drawing upon an analysis of the large corpus of 'rural' publications arising from this scholarly enterprise, this paper presents a chronologically structured overview of how rural geographical research at Aberdeen has reflected developments in, and contributed to, the evolution of the sub-discipline of rural geography.
\end{abstract}

Keywords: rural geographies, University of Aberdeen

\section{Introduction}

Given the regional context of the University of Aberdeen, serving an extensive and diverse rural hinterland, it is unsurprising that academics from a variety of disciplines within the institution have, for many years, focused their research upon rural places and rural communities. From the late 1800s onwards, many generations of Aberdeen students have studied Agriculture, Forestry and Rural Economics. During the first 50 years of the Geography Department (c. 1920-70), the focus on Regional Geography in the undergraduate curriculum (see Philip \& Edwards' contribution in this Special Issue) meant that rural places and rural populations were studied in UK and international 
contexts. An increased expectation from the 1960s that academic staff employed in UK universities would undertake research and publish their findings was as pertinent in Geography at Aberdeen as elsewhere. In this contribution we review topics framing such scholarship, drawing on an analysis of the published outputs of Geography staff whose research had a rural orientation. We present a chronologically structured illustration of how research by geographers at Aberdeen University has reflected developments in, and contributed to, the evolution of the sub-discipline of rural geography.

What is 'rural geography'? Overarching definitions presented in the literature include "the study of people, places and environments in rural areas with special reference to society, economy, politics and culture" (Cloke, 2000, p. 719) and "the study of people, places, and landscapes in rural areas, and of the social and economic processes that shape these geographies" (Woods, 2009, p. 429). These characterisations delimit an area of study that is based, at first glance, on a scholarly inheritance where the functional traits of rural spaces are mapped and analysed (Cloke, 2006). This includes the traditional foci of agriculture, resource management, land-use planning, migration, economic development, infrastructure and tourism (Woods, 2009). As with wider currents within human geography, the study of rural geographies has been influenced by contemporary themes and theoretical approaches. The objects of study, explanatory frameworks and methods deployed to interrogate 'rural issues' as well as the definition of 'rural', have all been influenced by prevailing paradigms associated with human geography and the wider social sciences (Cloke, 2006; Woods, 2011). These influences have extended the scope of rural geographies beyond descriptive categorisation and classification to embrace the complex, tangled and often messy patterns and processes that shape contemporary life and livelihoods in rural places. 


\section{Rural geographical research at Aberdeen: six decades of output}

Since the 1960s, rural geographical scholarship has been a feature of the research interests of a number of academics employed in Aberdeen's Geography Department. Only some of these individuals would have identified as 'rural geographers' although their research was concerned with rural contexts. This is not unusual. The use of a qualifying pre-fix to 'geographer', such as 'rural', 'political' or 'economic' was relatively uncommon until the latter decades of the twentieth century. In the first edition of the Dictionary of Human Geography, 'rural geography' was defined as "the study of the geographical aspects of human organization and activity in non-urban areas" and it was noted that "few human geographers call themselves rural geographers, but many are interested in topics which form part of rural geography" (White, 1981, p. 296). To this day, some academic geographers choose to style themselves as, for example, 'transport' or 'cultural' geographers rather than using the epithet 'rural', despite a prominent rural focus to their work. As this paper is concerned with the 'rural research' of academics employed within the Department of Geography since the 1960s, the matter of self-definition as a scholar of the rural, or otherwise, is apt because those undertaking research in rural contexts in the 1960s and 1970s are unlikely to have considered themselves as 'rural geographers' yet their work aligns with earlier and more recent definitions of what comprises rural geographical research. Also, accepting that rural geographical research may be conducted by those who do not consider themselves to be rural scholars per se allows for a broader reflection on the contributions to rural research made by Aberdeen geographers. 
A review of the published outputs of Aberdeen geographers whose work often reflected a rural focus was conducted using the open source software Publish or Perish through which lists of published outputs may be generated for individuals. The start date for the review is the date at which James Coull was appointed as Lecturer - 1959 a date that also marks the start of a rapid expansion of the Geography Department (Philip \& Edwards, this volume). Six decades worth of published outputs were thus compiled and analysed. The parameters of the Publish or Perish queries were set as the dates individuals were employed as members of core academic staff ${ }^{\mathrm{i}}$ in Geography at Aberdeen. Lists of publications (including, for example, academic journal papers, monographs, published research reports, published conference proceedings) and associated metrics (e.g. citations per output, year of publication) were generated for the following individuals:

(1) Those who may be defined as 'rural geographers': James (Jimmy) Coull (1959-96); Alexander (Sandy) Mather (1969-2015); John Farrington (1971-2016); John Bryden (1995-2004); Lorna Philip (2004-19); Aileen Stockdale (2004-06); Helmut Geist (2006-13); David Watts (2009-18); Katrin Prager (2018-19).

(2) Those whose work aligns with core rural geography topics: Brian Clark (1971-99); Colin Hunter (1995-2012); Hayden Lorimer (19982006); Antonio Ioris (2007-12).

The Publish or Perish queries identified a total of 545 outputs, 401 (co)authored by the 'rural geographers' and 144 (co-)authored by those whose work aligned with core rural geography topics. A handful of publications were double counted because they were collaborative outputs written by two or more of the 
individuals listed above. The titles were scrutinised to determine the topics covered in each contribution. An iterative approach was adopted to develop a thematic coding framework comprising twenty-two topics. Up to three topics were allocated per output to describe the subject matter of each publication. The geographical focus of the contribution was also categorised (e.g. UK, Europe). Two geographical classifications could be allocated to each output.

A geographical focus was identifiable from the title of 319 of the 556 outputs (57\%) authored by the individuals listed above. Most papers addressed only one geographical context, comparative perspectives were only identified from the titles of 14 papers. As shown in Table 1 outputs addressed both national and international contexts. There was a Scottish focus to 165 outputs, of which half were concerned with the Highlands and Islands. The North East of Scotland, the region within which the University of Aberdeen is situated, was the explicit focus of only eight outputs. Of the international contributions, the outputs by the 'rural geographers' were the most likely to have a European focus whilst the outputs with a rest of the world focus were overwhelmingly the products of geographers whose work aligned with rural geography themes.

From the iterative thematic analysis of publication titles, twenty-two topics framing rural geographical research emerged, undertaken by members of the Geography staff over the past sixty years. The titles indicated that three quarters of the publications dealt with two themes, a third considered three themes. The most common topics (those where the descriptive theme was applied 80 times or more) were natural resource management, environmental sustainability, economic development, rural policy, land use and planning, community development/sustainability and theoretical contribution. Figure 1 reports the number of times each topic occurred and clearly shows the wide 
range of topics Aberdeen geographers have explored. It also distinguishes between the rural geographers and other staff working on rural topics. For the latter group, $40 \%$ of outputs were aligned with just two themes, namely environmental sustainability (25\%) and natural resource management (16\%). For the rural geographers no single theme was associated with more than $12 \%$ of the publications which points to rural geographers' attempts to explore the complex intersections between a range of social, economic, political and cultural issues - research in which multiple themes must be interrogated, often simultaneously.

Having provided a broad overview of the research topics those with an interest in rural studies have undertaken, we now turn to consider how the research interests of staff over the past 60 years have reflected the broad developmental trends in UK rural geography over this period.

\section{Chronicling rural geography's development and the contribution to the evolution of the sub-discipline by Aberdeen geographers}

Throughout the twentieth century, rural places have been important to geographical research. As noted by Gregory, Little and Watts (2009, p.659), the origins of Vidal de la Blache's influential approach to Regional Geography was the study of peasant cultures in rural France, whilst Cultural Geography, as expounded by Sauer, was informed by the study of rural and agricultural landscapes in North America. 'Rural' geography was integral to both paradigms. Early spatial science-based research in the discipline was informed by, for example, von Thünen's model of agricultural land use. Hägerstrand's diffusion theory was developed from his studies of the Swedish countryside. Cloke identified the demise of Regional Geography as the cause of waning interest in research focused on rural places and rural communities and he noted that it was not until the 
1970s when "a distinctly demarcated subject area of 'rural geography' emerged" (Cloke, 2000, p.719) that rural areas once again became a more prominent focus for research undertaken by geographers.

The decline in Regional Geography during the 1950s and 1960s came at a time of geography staff and student numbers increasing at Aberdeen. New staff brought new ideas, and the status of Regional Geography as the basis of teaching and research was challenged. As observed in Philip and Edwards (this volume), the overhaul of the Honours curriculum that came into effect for the graduating class of 1971-72, which introduced Systematic Geography papers in the final examinations, supplanted the preeminence of the Regional Geography papers that had been central since the 1920 s. This change in the curriculum came at a time when rural geographical scholarship started to characterise some of the research undertaken in the Geography department and coincided with the publication, in 1972, of Clout's Rural Geography: an introductory survey which is credited with marking the interests of rural geographers expanding beyond agricultural research. As Cloke (2000) observed, "the literature of rural geography burgeoned in the 1970s and 1980s" (p. 719). We now assess whether developments in rural geographical scholarship were reflected in the research undertaken at Aberdeen.

\section{A burgeoning of rural geographical research: the 1960s and 1970s}

Jimmy Coull and Sandy Mather were the key proponents of rural geographical research at Aberdeen from the late 1960s onwards, although they were academics who might not have adopted the label 'rural geographer'. Their research aligned with some of the main areas of rural geographical research which by the mid-1980s were demarcated by White 
(1986, p. 414) as "(a) Depopulation, its causes and consequences; (b) the growth of the influence of urban related problems in rural areas, especially through second homes and dormitory villages; (c) the pattern of recreation and tourism in the rural environment; (d) structural changes in agriculture and their social and demographic implications; (e) rural planning". Coull and Mather's outputs reflected the 'scholarly inheritance' of rural geography in that their research was concerned with the functional characteristics of rural spaces, but their interests in fisheries and forestry respectively evolved to consider the wider economic, social, demographic and cultural issues aligned with the exploitation of natural resources. Coull, appointed as Lecturer in 1959, had a careerspanning interest in fishing and fishing communities. His research considered both historical and contemporary contexts: work on the fisheries of the North East of Scotland before 1800s, the Scottish herring fishery and the whaling industry (c.f. Coull, 1969, 1986, 1988, 1994a and 1994b) illustrate historical perspectives, while contemporary topics are illustrated in his work on crofter-fishermen in Norway (Coull, 1971), fisheries policy and management in Europe and Canada (Coull, 1992), fish farming in the Highlands and Islands (respectively Coull, 1971; 1992 and 1988). In the year of his retirement Coull published a monograph, The Sea Fisheries of Scotland: A historical geography, which compiled his extensive knowledge of Scottish fisheries.

Many of Mather's early publications arose from the Beach Surveys of Scotland programme of research funded by the Countryside Commission, but during the 1970s he also published on afforestation in Northern Scotland (Mather, 1971), red deer land use (Mather, 1971; 1972) and post-war land-use change in the Highlands and Islands of Scotland (1979). Research on land use and natural resource management, specifically forestry, became the focus of Mather's work from the 1980s onwards. Mather also made 
notable theoretical contributions to the international geographical literature on topics including forest transitions $(1994 ; 2004)$.

\section{Rural geographers and contributions to public policy and planning in rural areas: the 1980s and $1900 \mathrm{~s}$}

It was during the 1980s that rural geographers began to undertake research whose focus was to critically address issues related to public policy and planning in rural areas. This marked a departure from "broadly theory-free" (Gilg, 1985, p. 172) rural geography. During the 1980s the Conservative government at Westminster embarked upon a programme of de-nationalisation and privatisation of state assets. Changing publicprivate relationships underpinned some work undertaken at Aberdeen in the 1980s and early 1990s. For example, Mather examined the privatisation of forestry in Scotland (Mather, 1987) and the employment impacts of this move (Mather \& Murray, 1988). John Farrington (who would describe himself as a transport geographer despite more than half of his published outputs being based on 'rural' research) undertook studies of deregulation and privatisation in the British transport sector, work which also included a study of bus deregulation in rural Scotland (Farrington, 1985a, 1985b). Led by Brian Clark, tools for Environmental Impact Assessment were developed during the 1970s which led to the production of outputs that informed how this technique became embedded in land-use planning systems in the UK and elsewhere (c.f. Clark et al., 1978; 1984). Although not specifically 'rural' research, the Environmental Impact Assessment tools have influenced planning and development decision making that has affected many rural areas and rural communities. Such research illustrates how Aberdeen rural geographers and others started to work on policy-aligned and applied rural research, a trend that continues in the Department to this day. 
By the early 1990s rural geography had become more issue-based, with research often aligning with the following four key themes which both encompassed a focus on the agricultural sector and interactions between political, economic and social phenomenon in rural places: "the role of economic restructuring in bringing about uneven development; the recognition that restructuring does not occur in a social vacuum and that social recomposition occurs both as a shaping mechanism for restructuring ...; recognition that economic restructuring and social recomposition do not occur in an environmental vacuum, and that environmental recomposition is also relevant; and the role of the state in mediating or organizing change" (Cloke, 2000, p. 719, emphasis in original). These themes reflected some of the Economic and Social Research Council's thematic priorities at the time. The creation of the Arkleton Centre for Rural Development Research in 1995 (later renamed the Arkleton Institute), co-led by Mark Shucksmith from the former Department of Land Economy and John Bryden in the Geography Department, provided a focal point for interdisciplinary rural research at Aberdeen that responded to the emergence of more critical, issue-based rural research. It also brought applied research and critiques of (rural) policy to the fore. Research coalesced around the themes of economic performance and development, social inclusion and exclusion, environment and sustainability and governance and policy ${ }^{\mathrm{ii}}$ and was principally concerned with 'human dimensions' of rural development. The research approach advocated by the Arkleton Institute was an emphasis on people, comparative perspectives - including international work, and a relevance for policy and practice. This was considered to reflect the fact that, outwith academic circles, there was a growing interest in the rural economy and society beyond agriculture. For more than a decade, numerous research staff worked in the Arkleton Institute. Most of the Geography staff who undertook research 'in the rural' (Hunter, Mather, Philip, 
Stockdale and Lorimer) were affiliates of the Arkleton Institute and they and other academic staff supervised doctoral research on a wide range of rural social science topics.

Bryden's outputs reflected the Arkleton Institute's desire to undertake and promote research of relevance to rural policy and practice and to engage with research users (such as the European Commission, the Organisation for Economic Cooperation and Development, and UK government and devolved nation departments). Much of Bryden's work considered dimensions of rural policy, especially European rural policy, and how this influenced economic development in rural areas. Bryden led the Dynamics of Rural Areas (DORA) project, funded by a grant from the European Union's 4th Framework programme and outputs from this work included contributions to debates about future prospects for rural areas in Europe, including remote rural regions (e.g. Bryden, 1994; Bryden \& Dawe, 1998), rural development and global-local interactions (c.f. Bryden et al., 2001; 2005), rural employment in industrialised countries (Bryden \& Bollman, 2000) and rural development indicators (Bryden, 2002).

Post-modern and post-structural influences brought to the fore, from the 1990s, understandings of 'rurality' as a socio-cultural construct (Halfacree, 1993, 2006; Mormont, 1990) and new conceptual framings of rural geographical research such as nature-society, society-space and self-other became popular. The nature-society nexus informed work undertaken by, for example, Hunter, Geist and Ioris. Hunter's work on sustainable tourism (e.g. Hunter, 1995; 1997; 2002; Hunter \& Shaw, 2005) illustrated growing tensions between the environmental impacts of tourism and tourism being promoted in many quarters as a means by which rural areas could diversify their economies and develop a more sustainable economic future. Geist's work offered international perspectives on land-use change, informed by political ecology 
perspectives, including for example the global impacts of local land use and land-use cover changes (Lambin \& Geist, 2008), global economic drivers of local land-use change (Geist et al., 2008) human-environment relationships and desertification (Lambin et al., 2009) and agricultural transitions (Geist et al., 2006). Ioris' work also applied political ecology perspectives, in his case to the study of water resources and their governance. He conducted research in a Scottish context (e.g. Ioris, 2008a; Fish et al., 2010) and a corpus of work undertaken in South America (e.g. Ioris, 2008b; 2009; 2010).

Parallels between the development of human geographical research as a whole and rural geographical research specifically are illustrated in research conducted in the late 1990s which saw some rural scholars influenced by the cultural turn (c.f. Philo, 1992) and attending to difference and 'otherness', giving a voice to marginalised, overlooked and discriminated against individuals and groups. A concern with inequalities in rural society implicitly framed, for example, Farrington's work on accessibility in rural areas (Halden et al., 2002; Farrington \& Farrington, 2005), the development of an accessibility policy appraisal tool (Farrington et al., 2004) and rural community transport as a means of developing social capital and promoting social inclusion (Gray et al., 2006). Lorna Philip was one of four individuals who joined the staff of the Geography Department in 2004 following institutional changes that led to the closure of the Department of Land Economy, a department that had a strong reputation for rural social science research. Prior to her move to Geography, Philip had collaborated with her colleague and co-director of the Arkleton Institute, Mark Shucksmith, on work that conceptualised rural social exclusion (e.g. Philip \& Shucksmith, 2003), contributing to debates about inequalities in rural areas and how urban framings of inequality could lead to disadvantage in rural areas being overlooked. 
She also led Scottish Government-funded research identifying and illustrating issues of concern to public policy makers associated with ageing in rural Scotland (Philip et al., 2003). Following her move to Geography these interests in inequalities were furthered by research on income dynamics in rural areas (Gilbert et al., 2006; Philip \& Gilbert, 2007) and additional work on ageing in rural communities (Philip et al., 2012). A concern with inequalities continued to influence work undertaken by Farrington and Philip more recently, such as their contributions on urban-rural digital divides (e.g. Farrington et al., 2015; Philip et al., 2015) which are discussed below.

\section{Theoretical developments, lives in the rural and a digital turn in rural studies at}

\section{Aberdeen}

At the vanguard of some of the most recent theoretical developments in the discipline applied within rural contexts is work by Hayden Lorimer which he undertook whilst based in Geography at Aberdeen. His work clearly illustrates the influence of the 'critical turn' in Human Geography (theoretical perspectives that have influenced Human Geography in recent years). A cultural geographer, Lorimer's Aberdeen outputs included publications concerned with the performativity of walking in Scotland's mountains (e.g. Lorimer \& Lund, 2003), the cultural politics of deer stalking (Lorimer, 2000) and critical perspectives on 'seeing' the Scottish Highlands (Lorimer 1999).

Theoretical developments have also influenced the work of David Watts and Katrin Prager whose research provides examples of 'traditional' rural topics such as agriculture, hunting, and food production and consumption being 're-framed' by new theoretical and methodological approaches. Watts' work included examining the relocalisation of food (e.g. Little et al., 2009; Ricketts Hein \& Watts, 2010; Watts et al., 2011) and hunting cultures (Watts et al., 2017). Prager, the most recent addition to the 
Geography staff, joined the Aberdeen department from the James Hutton Institute where she had undertaken work that engaged with environmental management, landscape planning and participatory macroenvironmental policy (see for example: Prager, 2010, 2015; Prager et al., 2012, 2015). She has continued this work at the University of Aberdeen, notably exploring deer management (Prager et al., 2018). Her work illustrates a shift in thinking about the rural, moving from addressing functional land-use engagements towards contemporary, community-engaged and sustainable development orientated approaches to landscape research. These perspectives are evident in Prager's leadership of the MSc in Land Economy (Rural Surveying and Rural Property Management), widely referred to as the MLE.

Not explicitly theoretical, but also aligned with aspects of the critical turn whereby lived experiences and everyday lives are the focus of enquiry, was work on migration undertaken by Aileen Stockdale (one of those who joined Geography following institutional changes in 2004) whilst in the Geography Department at Aberdeen. She examined community consequences of in- and out-migration and relationships between migration and rural economic regeneration (c.f. Stockdale 2004, 2006). This interest in rural migration was developed further in work undertaken with Philip which examined migration as a driver of change in rural communities, specifically focusing on retirement transition migration (c.f. Stockdale et al., 2013; Philip et al., 2013; Philip \& MacLeod, 2018). Exploring lived experiences has also influenced Philip's work at the intersections between rural demographic ageing and health and wellbeing, work which aligns with the emerging area of scholarship referred to as rural gerontology (c.f. Currie et al., 2015; Philip et al., 2015; Dowds et al., 2018).

The rapid development of information and communication technologies (ICT) and associated digitisation of the economy and everyday lives provided the context for 
the most recent developments in rural geographical scholarship undertaken at Aberdeen. In 2009 an $£ 11.8$ million award was received from the Research Councils’ UK Digital Economy programme to support, for six years, the dot.rural Digital Economy Hub. At the time this was the largest single grant the University of Aberdeen had ever received. Co-led by John Farrington, interdisciplinary research undertaken within the umbrella of the dot.rural hub spearheaded a 'digital turn' in rural social science research (exemplified by, for example, the formation of a Digital Geographies Research Group within the Royal Geographical Society - Institute of British Geographers). Philip led research conducted under the 'health' theme (e.g. Mort and Philip, 2014; Roberts et al, 2015) and in the early phase of dot.rural, Hunter worked on digital tourism and community heritage research conducted under the 'culture' theme. Farrington and Philip's work on digital divides and territorial digital inequalities contributed to emerging debates about new forms of rural inequality (e.g. Ashmore et al., 2015; Farrington et al., 2015; Philip et al., 2017) and the potential impacts for mostly remote and sparsely populated rural communities and rural businesses left behind by advances in ICT infrastructure (e.g. Williams et al., 2016; Philip \& Williams, 2019).

\section{Concluding reflections}

Although the sub-discipline of rural geography remains small in comparison with others from within human geography, such as transport geography, urban geography or economic geography, rural as a category and construct that frames geographical research is a vibrant field, albeit one whose proponents are employed in a relatively small number of UK Higher Education institutions. Rural geographies and other geographical enquiries that focus attention on rural places and communities remain a 
prominent feature of academic endeavour at the University of Aberdeen. Sixty years of rural geographical research at Aberdeen is testament to the enduring relevance of 'rural' as a meaningful category/concept in academic discourse (a solid rebuttal to Hoggart's 1990 suggestion that geographers should do away with rural as an analytical category) and as an influence in everyday lives. As Woods (2011, p. 8) observed, rural continues to have "a powerful meaning for many people".

Successive generations of undergraduate students have been taught key concepts in rural geography, in the introductory geography courses offered at First and Second year and in specialist Honours options. The Rural Geographies Honours option is one of the most popular in the suite of Honours courses offered to undergraduates as the Department enters its second century. Rural studies underpinned the curriculum of the taught postgraduate MSc in Rural and Regional Resources Planning/ Sustainable Rural Development programme delivered over almost four decades. The MSc in Environmental Partnership Management degree currently offered by the Department also introduces students to many contemporary rural geographical concepts and debates. Since 2004, Geography at Aberdeen has been responsible for the delivery of the Master of Land Economy Rural Land and Business Management programme. Accredited by the Royal Institution of Chartered Surveyors, this degree prepares those who wish to pursue a career in the rural surveying profession, teaching them traditional land-based skills alongside more critical perspectives on rural planning, development and policy. Both taught postgraduate degrees have a strong applied dimension, drawing upon the strengths and diversity of the research, policy contributions and wider impacts made by departmental staff. The research postgraduate community has also embraced rural geographical research for many years and many doctoral students have gone on to research positions in Universities, Research Institutes and Government. 
Rural geographers, like many others in the discipline, have demonstrated an openness to interdisciplinary research and, at Aberdeen, rural research over the past thirty years has involved collaborations with University colleagues from disciplines as diverse as Agriculture, Anthropology, Computing Science, Economics, Engineering, Forestry and Public Health. There is a long history of Geography staff collaborating with rural social science researchers at the James Hutton Institute (formerly the Macaulay Land Use Research Unit), undertaking research and co-supervising PhD candidates. These activities retain links between University staff and former postgraduate students and research staff and facilitate the development of new research relationships with others in the rural social sciences. Philip and Prager are actively sustaining this collaborative tradition today. Membership of the Trans-Atlantic Rural Research Network and, more recently, the Aberdeen University - Curtin University (Australia) alliance has offered the potential for international collaborations between academics and research students interested in rural places and rural communities.

Rural geographical research at Aberdeen today is a lively component of ongoing Human Geography research being undertaken by staff and research postgraduate students. We hope that future generations of Aberdeen staff and students sustain and interest in topics aligned with rural geographical scholarship and that research focusing upon rural places and the people who live and work therein will continue in the Geography department's second century.

\section{References}

Ashmore, F. H., Farrington, J. H., \& Skerratt, S. (2015). Superfast Broadband and Rural Community Resilience: Examining the Rural Need for Speed. Scottish Geographical Journal, 131(3-4), 265-278. http://doi.org/10.1080/14702541.2014.978808 
Bryden J, Hart, K. (2005) A New Approach to Rural Development in Europe Germany, Greece, Scotland and Sweden, Lewiston, Queenston, Lampeter: The Edwin-Mellon Press

Bryden, J. \& Dawe, S. P. (1998). Development strategies for remote rural regions: What do we know so far. Contribution to the OECD International Conference On Remote Rural Areas: Developing Through Natural and Cultural Assets. 1998. 16 pages. Available at https://www.academia.edu/17486574/Development_strategies_for_remote_rural _regions_what_do_we_know_so_far

Bryden, J. (1994). Prospects for rural areas in an enlarged Europe. Journal of Rural Studies, 10(4), 387-394. http://doi.org/10.1016/0743-0167(94)90048-5

Bryden, J. (2002) Rural Development Indicators and Diversity in the European Union. Paper presented at the conference of measuring rural diversity, Washington, DC. Available From: https://www.researchgate.net/publication/228865950_Rural_Development_Indic ators_and_Diversity_in_the_European_Union [Accessed 23/4/2019]

Bryden, J., \& Bollman, R. (2000). Rural employment in industrialised countries. Agricultural Economics, 22(2), 185-197. http://doi.org/10.1016/S01695150(99)00053-5

Bryden, J., Efstratoglou, S., Persson, L. O., Schrader, H., Atterton, J., Ceccato, V., Courtney, P., Efstratoglou, A., Hachmöller, G., Hart, K., Koch, B., Kouroussi, E., Masurek, L., Apostolos Papadopoulos, A., and Timm, A. (2001) Dynamics of Rural Areas (DORA). Final report to Eurostat.

Clark, B. D. (1984). Environmental Impact Assessment (EIA): Scope and Objectives. In Perspectives on Environmental Impact Assessment (pp. 3-13). Dordrecht: Springer Netherlands. http://doi.org/10.1007/978-94-009-6381-8_1

Clark, B. D., Chapman, K., Bisset, R., \& Wathern, P. (1978). Methods of Environmental Impact Analysis. Built Environment (1978-), 4(1) pp. 111-121. http://doi.org/10.2307/23284628

Cloke, P. (2000). Rural Geography. In R. J. Johnston, D. Gregory, G. Pratt, \& W. M (Eds.), The Dictionary of Human Geography (4th Edition, pp. 719-720). Oxford: Blackwell Publishing Ltd. 
Cloke, P. (2006). Conceptualizing rurality. In P. Cloke, T. Marsden, \& P. H. Mooney (Eds.), Handbook of Rural Studies (pp. 18-29). London: Sage.

Coull, J. R. (1969). Fisheries in the North-East of Scotland before 1800. Scottish Studies, 13, 20-1.

Coull, J. R. (1986). The Scottish herring fishery 1800-1914: Development and intensification of a pattern of resource use. Scottish Geographical Magazine, 102(1), 4-17. http://doi.org/10.1080/00369228618736643

Coull, J. R. (1988). Fish farming in the highlands and islands: Boom industry of the 1980s. Scottish Geographical Magazine, 104(1), 4-13. http://doi.org/10.1080/00369228818736722

Coull, J. R. (1992). A comparison of fisheries policy and management in the European Community and Eastern Canada. Ocean \& Coastal Management, 18(2-4), 351369. http://doi.org/10.1016/0964-5691(92)90036-K

Coull, J. R. (1994). The whaling controversy in Shetland and the Hebrides in the early twentieth century. Northern Scotland, 14 (First Series (1), 55-68. http://doi.org/10.3366/nor.1994.0005

Coull. J. R. (1971). Crofter-fishermen in Norway and Scotland. Aberdeen: Dept. of Geography, University of Aberdeen. Retrieved from https://books.google.co.uk/books/about/Crofter_fishermen_in_Norway_and_Sco tland.html?id=Rn0nAQAAMAAJ\&redir_esc $=y$

Coull. J. R. (1996). The Sea Fisheries of Scotland: A Historical Geography. Edinburgh: John Donald.

Currie, M., Philip, L. J., \& Roberts, A. (2015). Attitudes towards the use and acceptance of eHealth technologies: a case study of older adults living with chronic pain and implications for rural healthcare. BMC Health Services Research, 15(1), 162. http://doi.org/10.1186/s12913-015-0825-0

Dowds, G., Currie, M., Philip, L., \& Masthoff, J. (2018). A Window to the Outside World. Digital Technology to Stimulate Imaginative Mobility for Housebound Older Adults in Rural Areas. In Geographies of Transport and Ageing (pp. 101130). Cham: Springer International Publishing.

Farrington, J. H. (1985). Transport Geography and Policy: Deregulation and Privatization. Transactions of the Institute of British Geographers, 10(1), 109119. http://doi.org/10.2307/622253 
Farrington, J. H., \& Harrison, R. J. (1985). Scotmap, rural bus services and deregulation. Scottish Geographical Magazine, 101(2), 111-123. http://doi.org/10.1080/00369228518736625

Farrington, J., \& Farrington, C. (2005). Rural accessibility, social inclusion and social justice: towards conceptualisation. Journal of Transport Geography, 13(1), 1-12. http://doi.org/10.1016/J.JTRANGEO.2004.10.002

Farrington, J., Philip, L., Cottrill, C., Abbott, P., Blank, G., \& Dutton, W. H. (2015). Two-Speed Britain: Rural Internet Use. Aberdeen University Press. Available at http://www.dotrural.ac.uk/two-speed-britain/

Farrington, JH., Shaw, J., Richardson, T., MacLean, M., Bristow, G., Halden, D. \& Leedal, M. (2004). Settlements, Services \& Access: The Development of Policies to Promote Accessibility in Rural Areas in Great Britain. Unknown Publisher, Welsh Assembly Govt. (With HM Treasury Countryside Agency and Scottish Executive).

Fish, R. D., Ioris, A. A. R., \& Watson, N. M. (2010). Integrating water and agricultural management: Collaborative governance for a complex policy problem. Science of The Total Environment, 408(23), 5623-5630. http://doi.org/10.1016/J.SCITOTENV.2009.10.010

Geist, H. J., Otañez, M., \& Kapito, J. (2008). The tobacco industry in Malawi: A globalised driver of local land change. In Andrew Millington \& Wendy Jepson (Eds.), Land change science in the tropics: Changing agricultural landscapes (pp. 251-268). New York: Springer Science + Business Media. Retrieved from https://abdn.pure.elsevier.com/en/publications/the-tobacco-industry-in-malawia-globalised-driver-of-local-land-

Geist, H., Lambin, E., Palm, C., \& Tomich, T. (2006). Agricultural transitions at dryland and tropical forest margins: actors, scales and trade-offs In: Brouwer F., McCarl B.A. (eds) Agriculture and climate beyond 2015. Environment \& policy, vol 46. Springer, Dordrecht

Gilbert, A., Philip, L., \& Shucksmith, M. (2006). Rich and poor in the countryside. In P. Lowe \& L. Speakman (Eds.), The ageing countryside (pp. 69-93). London: Commission for Rural Communities and Age Concern.

Gilg, A. W. (1985). An introduction to rural geography. Baltimore: E. Arnold. 
Gray, D., Shaw, J. \& Farrington, J. (2006). Community Transport, Social Capital and Social Exclusion in Rural Areas. Area, 38(1), 89-98. Retrieved from https://www.jstor.org/stable/20004505?seq=1\#metadata_info_tab_contents Gregory, D., Little, J., \& Watts, M. J. (2009). Rural Geography. In D. Gregory, R. Johnston, G. Pratt, M. J. Watts, \& S. Whatmore (Eds.), The Dictionary of Human Geography (5th Edition, pp. 650-659). Oxford: Wiley-Blackwell.

Halden, D., Farrington, J. H., Copus, A. K. (2002). Rural accessibility. Edinburgh: Scottish Executive Central Research Unit.

Halfacree, K. H. (1993). Locality and social representation: Space, discourse and alternative definitions of the rural. Journal of Rural Studies, 9(1), 23-37. https://doi.org/10.1016/0743-0167(93)90003-3

Halfacree, K. H. (2006). Rural space: constructing a three-fold architecture. In P. Cloke, T. Marsden, \& P. Mooney (Eds.), Handbook of Rural Studies (pp. 44-62). London: Sage.

Hunter, C. (1997). Sustainable tourism as an adaptive paradigm. Annals of Tourism Research, 24(4), 850-867. https://doi.org/10.1016/S0160-7383(97)00036-4

Hunter, C. (2002). Sustainable Tourism and the Touristic Ecological Footprint. Environment, Development and Sustainability, 4(1), 7-20. https://doi.org/10.1023/A:1016336125627

Hunter, C. J. (1995). On the need to reconceptualise sustainable tourism development. Journal of Sustainable Tourism, 3(3), 155-165. https://doi.org/10.1080/09669589509510720

Hunter, C., \& Shaw, J. (2005). Applying the ecological footprint to ecotourism scenarios. Environmental Conservation, 32(04), 294. https://doi.org/10.1017/S0376892906002591

Ioris, A. A. R. (2007). The Troubled Waters of Brazil: Nature Commodification and Social Exclusion. Capitalism Nature Socialism, 18(1), 28-50. https://doi.org/10.1080/10455750601164618

Ioris, A. A. R. (2008a). Water institutional reforms in Scotland: Contested objectives and hidden disputes. Water Alternatives, 1 (2), p. 253-270.

Ioris, A. A. R. (2008b). The limits of integrated water resources management: a case study of Brazil's Paraíba do Sul River Basin. Sustainability: Science, Practice and Policy, 4(2), 4-11. https://doi.org/10.1080/15487733.2008.11908017 
Ioris, A. A. R. (2009). Water reforms in Brazil: opportunities and constraints. Journal of Environmental Planning and Management, 52(6), 813-832. https://doi.org/10.1080/09640560903083756

Ioris, A. A. R. (2010). The Political Nexus between Water and Economics in Brazil: A Critique of Recent Policy Reforms. Review of Radical Political Economics, 42(2), 231-250. https://doi.org/10.1177/0486613410368499

Lambin, E. F., Geist, H. J., Reynolds, J. F., \& Smith, D. M. S. (2009). Coupled humanenvironment system approaches to desertification: Linking people to pixels. In Achim Röder \& Joachim Hill (Eds.), Recent advances in remote sensing and geoinformation processing for land degradation assessment (pp. 3-14). Leiden: CRC Press/Balkema. Retrieved from https://abdn.pure.elsevier.com/en/publications/coupled-human-environmentsystem-approaches-to-desertification-li

Little, J., Ilbery, B., \& Watts, D. (2009). Gender, Consumption and the Relocalisation of Food: A Research Agenda. Sociologia Ruralis, 49(3), 201-217. https://doi.org/10.1111/j.1467-9523.2009.00492.x

Lorimer, H. (1999). Ways of seeing the Scottish Highlands: marginality, authenticity and the curious case of the Hebridean blackhouse. Journal of Historical Geography, 25(4), 517-533. https://doi.org/10.1006/JHGE.1999.0165

Lorimer, H. (2000). Guns, Game and the Grandee: The Cultural Politics of Deerstalking in the Scottish Highlands. Ecumene, 7(4), 403-431. https://doi.org/10.1177/096746080000700402

Lorimer, H., \& Lund, K. (2003). Performing Facts: Finding a Way over Scotland's Mountains. The Sociological Review, 51(2_suppl), 130-144. https://doi.org/10.1111/j.1467-954X.2004.00455.X

Mather, A. S. (1971). Problems of Afforestation in North Scotland. Transactions of the Institute of British Geographers, (54), 19-32. https://doi.org/10.2307/621359

Mather, A. S. (1972). Red deer land use in the northern highlands. Part 1: The resource. Scottish Geographical Magazine, 88(1), 36-47. https://doi.org/10.1080/00369227208736206

Mather, A. S. (1972). Red deer land use in the Northern highlands. Part 2: Exploitation of the resource. Scottish Geographical Magazine, 88(2), 86-99. https://doi.org/10.1080/00369227208736216 
Mather, A. S. (1978). The alleged deterioration in hill grazings in the Scottish Highlands. Biological Conservation, 14(3), 181-195. https://doi.org/10.1016/0006-3207(78)90010-1

Mather, A. S. (1979). Land-use changes in the Highlands and Islands, 1946-75: A statistical review. Scottish Geographical Magazine, 95(2), 114-122. https://doi.org/10.1080/00369227908736428

Mather, A. S. (1992). The Forest Transition. Area, 24(4), 367-379. Retrieved from https://www.jstor.org/stable/pdf/20003181.pdf

Mather, A. S. (1994). Policy reform and institutional restructuring: the case of the Forestry Commission. Progress in Rural Policy and Planning, 4, 69-78.

Mather, A. S. (1994). Policy reform and institutional restructuring: the case of the Forestry Commission. Progress in Rural Policy and Planning, 4, 69-78.

Mather, A. S., \& Murray, N. C. (1987). Employment and private-sector afforestation in Scotland. Journal of Rural Studies, 3(3), 207-218. https://doi.org/10.1016/07430167(87)90070-2

Mormont, M. (1990). Who is rural? Or, how to be rural: Towards a sociology of the rural. In T. Marsden, P. Lowe, \& S. Whatmore (Eds.), Rural Restructuring: Global Processes and their Responses (pp. 21-44). London: David Fulton.

Mort, A., \& Philip, L. J. (2014). Social isolation and the perceived importance of inperson care amongst rural older adults with chronic pain: A review and emerging research agenda. Journal of Pain Management, 7(1), 13-21. Retrieved from https://psycnet.apa.org/record/2016-10249-003

Philip L.J., Gilbert A, Mauthner N., \& Phimister, E. (2003) Scoping Study of Older People in Rural Scotland Scottish Executive Central Research Unit, Edinburgh (118pp).

Philip, L. J., \& Gilbert, A. (2007). Low Income amongst the Older Population in Great Britain: A Rural/Non-rural Perspective on Income Levels and Dynamics. Regional Studies, 41(6), 735-746. https://doi.org/10.1080/00343400701281717

Philip, L. J., \& MacLeod, M. (2018). Tales from a Small Island: Applying the 'PathDependency"' Thesis to Explore Migration to a Remote Rural Community.' Sociologia Ruralis, 58(1), 147-170. https://doi.org/10.1111/soru.12142 
Philip, L. J., \& Shucksmith, M. (2003). Conceptualizing Social Exclusion in Rural Britain. European Planning Studies, 11(4), 461-480. https://doi.org/10.1080/09654310303646

Philip, L. J., Brown, D., \& Stockdale, A. (2012). Demographic ageing in rural areas: insights from the UK and US. In Rural Transformations and Rural Policies in the US and UK. London: Routledge.

Philip, L. J., Cottrill, C., \& Farrington, J. (2015). 'Two-speed' Scotland: Patterns and Implications of the Digital Divide in Contemporary Scotland. Scottish Geographical Journal, 131(3-4), 148-170. https://doi.org/10.1080/14702541.2015.1067327

Philip, L. J., Macleod, M., \& Stockdale, A. (2013). Retirement Transition, Migration and Remote Rural Communities: Evidence from the Isle of Bute. Scottish Geographical Journal, 129(2), 122-136. https://doi.org/10.1080/14702541.2013.783616

Philip, L., \& Williams, F. (2019). Remote rural home based businesses and digital inequalities: Understanding needs and expectations in a digitally underserved community. Journal of Rural Studies, 68, 306-318. https://doi.org/10.1016/J.JRURSTUD.2018.09.011

Philip, L., Cottrill, C., Farrington, J., Williams, F., \& Ashmore, F. (2017). The digital divide: Patterns, policy and scenarios for connecting the 'final few' in rural communities across Great Britain. Journal of Rural Studies, 54, 386-398. https://doi.org/10.1016/J.JRURSTUD.2016.12.002

Philip, L., Roberts, A., Currie, M., \& Mort, A. (2015). Technology for Older Adults: Maximising Personal and Social Interaction: Exploring Opportunities for eHealth to Support the Older Rural Population with Chronic Pain. Scottish Geographical Journal, 131(3-4), 181-193. https://doi.org/10.1080/14702541.2014.978806

Prager, K. (2010). Local and Regional Partnerships in Natural Resource Management: The Challenge of Bridging Institutional Levels. Environmental Management, 46(5), 711-724. http://doi.org/10.1007/s00267-010-9560-9

Prager, K. (2015). Agri-environmental collaboratives for landscape management in Europe. Current Opinion in Environmental Sustainability, 12, 59-66. http://doi.org/10.1016/J.COSUST.2014.10.009 
Prager, K., Lorenzo-Arribas, A., Bull, H., Slaaen Kvernstuen, M., Loe, L. E., \& Mysterud, A. (2018). Social constraints in cross-boundary collaborative deer management. Ecology and Society, 23(4), art29. http://doi.org/10.5751/ES10549-230429

Prager, K., Nienaber, B., Neumann, B., \& Phillips, A. (2015). How should rural policy be evaluated if it aims to foster community involvement in environmental management? Journal of Rural Studies, 37, 120-131. http://doi.org/10.1016/J.JRURSTUD.2014.12.006

Prager, K., Reed, M., \& Scott, A. (2012). Encouraging collaboration for the provision of ecosystem services at a landscape scale-Rethinking agri-environmental payments. Land Use Policy, 29(1), 244-249. http://doi.org/10.1016/J.LANDUSEPOL.2011.06.012

Ricketts Hein, J., \& Watts, D. (2010). Local food activity in the Republic of Ireland and Great Britain. Irish Geography, 43(2), 135-147. https://doi.org/10.1080/00750778.2010.514733

Roberts, A., Philip, L., Currie, M. and Mort, A. (2015) Striking a balance between inperson care and the use of eHealth to support the older rural population with chronic pain. International Journal of Qualitative Studies on Health and Wellbeing 10:27536. DOI: http://dx.doi.org/10.3402/qhw.v10.27536

Stockdale, A. (2004). Rural Out-Migration: Community Consequences and Individual Migrant Experiences. Sociologia Ruralis, 44(2), 167-194. https://doi.org/10.1111/j.1467-9523.2004.00269.x

Stockdale, A. (2006). Migration: Pre-requisite for rural economic regeneration? Journal of Rural Studies, 22(3), 354-366. https://doi.org/10.1016/J.JRURSTUD.2005.11.001

Stockdale, A., MacLeod, M., \& Philip, L. (2013). Connected Life Courses: Influences on and Experiences of 'Midlife'” In-Migration to Rural Areas.' Population, Space and Place, 19(3), 239-257. https://doi.org/10.1002/psp.1709

Watts, D., Leat, P., \& Revoredo-Giha, C. (2011). Local Food Activity in Scotland: Empirical Evidence and Research Agenda. Regional Studies, 45(9), 1187-1205. https://doi.org/10.1080/00343400903380416

Watts, D., Matilainen, A., Kurki, S. P., Keskinarkaus, S., \& Hunter, C. (2017). Hunting cultures and the 'northern periphery': Exploring their relationship in Scotland 
and Finland. Journal of Rural Studies, 54, 255-265.

https://doi.org/10.1016/J.JRURSTUD.2017.06.017

White, P. E. (1981) Rural Geography. In R. Johnston (Ed.) the Dictionary of Human Geography (First Edition, p. 296-297). Oxford, Blackwell.

White, P. E. (1986). Rural Geography. In R. Johnston, D. Gregory, D. M. Smith, P. Haggett, \& D. R. Stoddart (Eds.), The Dictionary of Human Geography (Second Edition, p. 414). Frome and London: Blackwell.

Williams, F., Philip, L., Farrington, J., \& Fairhurst, G. (2016). 'Digital by Default' and the 'hard to reach': Exploring solutions to digital exclusion in remote rural areas. Local Economy: The Journal of the Local Economy Policy Unit, 31(7), 757777. https://doi.org/10.1177/0269094216670938

Woods, M. (2009). Rural Geography. In R. Kitchin \& N. Thrift (Eds.), International Encyclopaedia of Human Geography (pp. 429-442). Oxford: Elsevier. 
Table 1: Geographical focus of rural geographical research undertaken at Aberdeen, $1959-2019$

\begin{tabular}{|l|c|c|c|c|}
\hline & Scotland & $\begin{array}{c}\text { UK wide or } \\
\text { England and/or } \\
\text { Wales and/or } \\
\text { Northern Ireland }\end{array}$ & $\begin{array}{c}\text { Europe } \\
\text { (including } \\
\text { Scandinavia) }\end{array}$ & $\begin{array}{c}\text { Rest of } \\
\text { world }\end{array}$ \\
\hline Contributions by rural geographers & $52 \%$ & $24 \%$ & $16 \%$ & $8 \%$ \\
\hline $\begin{array}{l}\text { Contributions by other geographers } \\
\text { whose work aligns with rural } \\
\text { geography themes. }\end{array}$ & $40 \%$ & $11 \%$ & $3 \%$ & $46 \%$ \\
\hline All contributions & $49 \%$ & $22 \%$ & $14 \%$ & $15 \%$ \\
\hline
\end{tabular}


Figure 1. Themes of outputs (1959 to 2019) authored by members of staff in the Department of Geography, University of Aberdeen

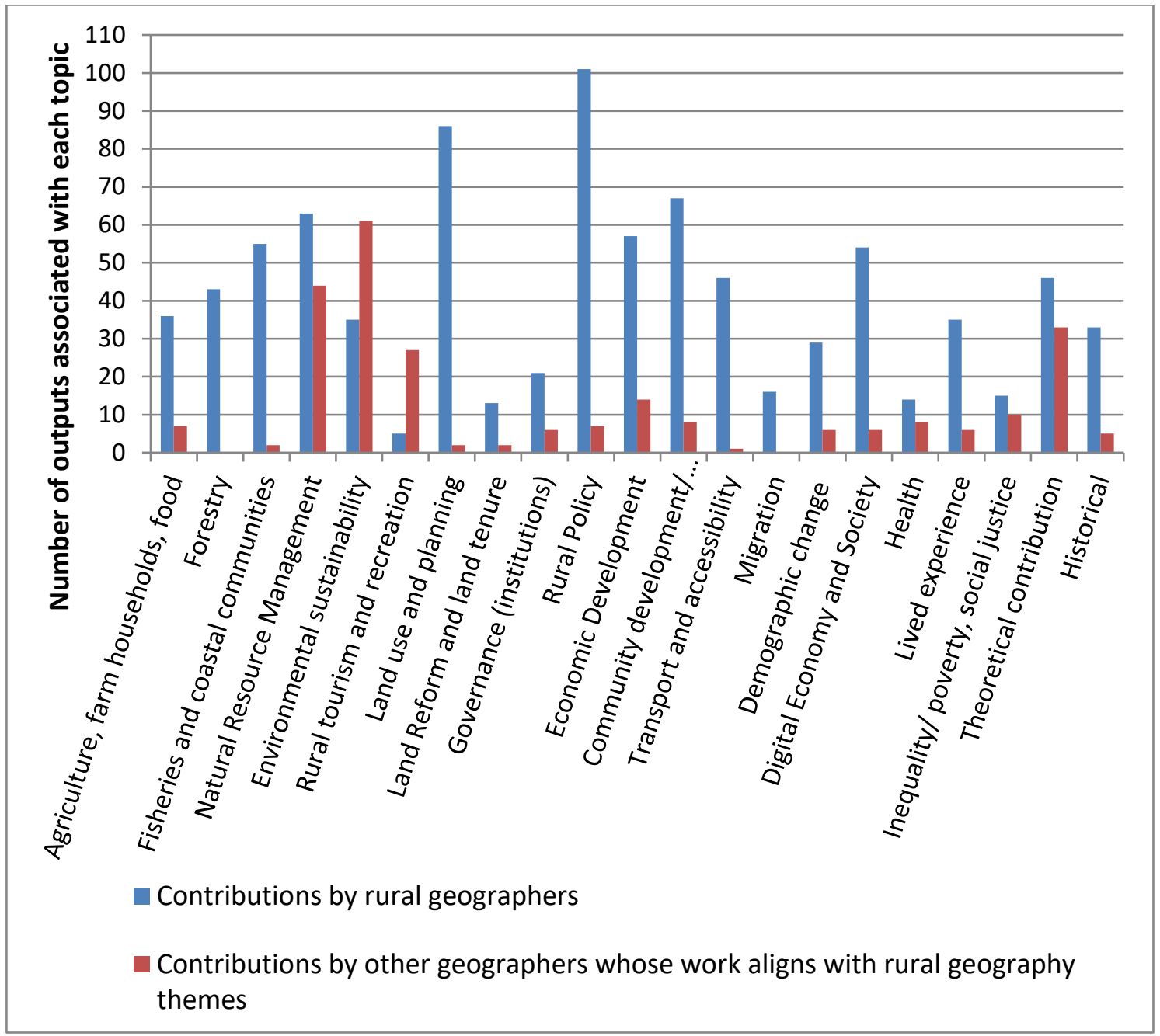


${ }^{\mathrm{i}}$ Many other researchers including, for example, those employed as Research Fellows or undertaking doctoral research, have made contributions to Aberdeen's corpus of rural geographical scholarship. This work is not referred to in this contribution due to the difficulty of compiling an accurate list of all those individuals who have undertaken research degrees or held research positions over the past 50 years or so. The contributions of these staff and research students, and that of their contemporaries working in St Mary's at the time of writing this article, to the vibrancy of rural research in Geography at Aberdeen has been and continues to be considerable.

ii The Arkleton Institute's web pages were archived in 2014. The authors acknowledge the help provided by Debbie Hay in Aberdeen University's IT services web team who extracted a copy of this archived content for us which provided much of the detail reported here. 